\title{
The effects of differentiated instruction on Turkish students' L2 achievement, and student and teacher perceptions
}

\author{
Ahmet Cihat Yavuz a * \\ a NUN Schools, Beykoz, İstanbul, 34973, Turkey
}

Received 2 August 2019 | Received in revised form 11 July 2020 | Accepted 13 July 2020

\begin{abstract}
APA Citation:
Yavuz, A. C. (2020). The effects of differentiated instruction on Turkish students' L2 achievement, and student and teacher perceptions. Eurasian Journal of Applied Linguistics, 6(2), 313-335.
\end{abstract}

Doi: $10.32601 /$ ejal.776002

\begin{abstract}
Endeavors have been invested to account for inefficient instruction, which is frequently attributed to disregarding learner idiosyncrasies. As a matter of course, differentiated instruction has begun to receive scholarly and professional attention in the hopes of ameliorating learner outcomes through learneraware teaching. Despite a great deal of recorded research, little is known about how differentiated instruction is prepared and operationalized. This study, conducted at a private high school in Istanbul, Turkey, investigated the impact of differentiated instruction on Turkish L2 learners' L2 achievement along with the perceptions of learners and teacher. Two intact classes were selected as control $(\mathrm{N}=14)$ and DI group $(\mathrm{N}=8)$. The control group was exposed to traditional instruction, while the DI group received differentiated instruction guided by the principles of constructivism, multiple intelligence theory (Gardner, 1993), and the differentiated instruction framework of Tomlinson (1999). Data collected by means of L2 achievement tests revealed that DI group outperformed the control group in overall L2 achievement. Learner reflective essays revealed that Turkish L2 learners found differentiated instruction as distinctive, entertaining, engaging, instructive, and interest-related, while teacher reflective journals raised the issues of time constraints, needs for learner awareness and training about differentiated instruction.
\end{abstract}

(C) 2020 EJAL \& the Authors. Published by Eurasian Journal of Applied Linguistics (EJAL). This is an open-access article distributed under the terms and conditions of the Creative Commons Attribution license (CC BY-NC-ND) (http://creativecommons.org/licenses/by-nc-nd/4.0/).

Keywords: Differentiated instruction, differentiated L2 Instruction, traditional L2 instruction

\section{Introduction}

The significance of adapting instruction to individual differences has been recognized since the fourth century BC (Anderson, 1995). As a result of the increasing heterogeneity of students, educational research and policies focused their attention on these differences (Tomlinson, 2005). Despite teachers' acknowledgement of the need to cater to student diversities, they insist on using a one-size-fits-all approach in their

\footnotetext{
* Corresponding author. Tel: +90-554-771-4686

E-mail addresses: ahmetcihatyavuz@gmail.com http://dx.doi.org/10.32601/ejal.776002
} 
classrooms and overlooking students' individuality (Tomlinson \& Kalbfleisch, 1998). The one-size-fits-all approach, as its name suggests, is based on the underpinning that all learners are treated in an egalitarian way by disregarding the wide range of diversity. However, it was not until recently that individual differences received surging interest, and failures in learner learning started to be attributed to the onesize-fits-all approach (Kasteloot, 2011). This consciousness has attracted mindful attention on differentiated instruction (hereinafter DI) among educators and researchers, and the demand for coping with learner diversities has become inexorable. DI, in contrast to the one-size-fits-all approach, considers diversities among learners, and assumes addressing these differences. Having said that, dealing with learner differences is highly ambitious, as it is potentially related to a vast array of aspects such as learner readiness, needs, interests, styles, capabilities, and level of development (Tomlinson et al., 2003). In the same vein, DI has multiple avenues to attend to these differences (Blaz, 2006), such as grouping learners according to their interest or level, setting individual learning outcomes, providing more instructional support through different sorts of materials, adapting course materials, giving more encouragement and time, and allowing for more in-depth exploration (Heacox, 2012; Tomlinson, 2005).

Although DI looks like a potential solution for grappling with learner differences, and thus maximizing achievement, most teachers maintain traditional instruction and abstain from espousing DI in their contexts, which is substantiated by research on teacher perception, specifically finding DI time-consuming (Njagi, 2014; Siam \& AlNatour, 2016; Stewart, 2016; Theisen, 2002) and necessitating particular knowledge base (Lunsford 2017; Oliver, 2016; Robinson, Maldonado, \& Whaley, 2014). Hence, familiarity with the procedure of DI has not been established due to its equivocal perceptions, lack of scholarly effort, and eschewing any undertaking in educational contexts. While much has been reported about perceptual understanding and encountered barriers during implementation, little has been scrutinized for the sake of providing a pattern that is grounded in theory and structured through a variety of strategies. The current study will thus seek fulfilling this need through its wellconstructed procedure.

In the following sections, the conceptual base of the study is firstly discussed with an emphasis on theoretical underpinnings that informed the structure of the DI, and then the implementation of DI is given by breaking it down into its characteristics and existing strategies.

\subsection{Theoretical Framework}

Tomlinson and McTighe (2006) defined DI as proactive planning informed by varied approaches to what learners should learn, how they will learn, and how they will demonstrate their learning in an attempt to reach out to each learner. It allows teachers to utilize varied instructional strategies to meet needs of each learner. In other words, teachers are flexible in tailoring the content, such as facts, concepts, and 
principles (Blaz, 2006; Theisen, 2002; Tomlinson, 1999); the process, the way learners understand a key concept or develop the target skill (McCarthy, 2015; Tomlinson, 2001) and the product, the means by which learners show their understanding (Tomlinson, 1999). DI incorporates instructional strategies informed by learner varieties that provide significant information for teachers (Chung, 2005) and implemented considering various aspects of teaching.

The reconstruction of the aforementioned curricular elements requires full awareness of each learner in terms of their readiness -entry point to a specific concept or skill- (Tomlinson, 2014), interest through which teachers can relate lesson content to learners interests and boost motivation, and learning style which is determined by dominant intelligence (Dunn \& Dunn, 1979; Gardner, 1993). Readiness of learners is traditionally determined through placement or achievement tests, whereas interest and learning styles, if attempted, are verified through surveys, observation and the other means. DI hinging on these three characteristics of learners discernibly opposes the one-size-fits-all mindset (Lewis, Rivera \& Roby, 2012), for it is designed to cohere with students' readiness, interest, and learning style, and is enriched by instructional strategies such as tiered activities, choices, and flexible grouping. Yet, DI is not merely constituted by a set of strategies but grounded in and starts from a mindset assuming that each learner learns differently, and a single teaching style does not suit them when it is not conformed to their individual diversities. Thus, DI should be embraced by teachers in order to cope with individual differences and to optimize learning outcome rather than simply experiment a set of instructional strategies (Suprayogi \& Valcke, 2016).

\subsection{Previous studies}

There has been a burgeoning interest in the research dedicated to DI for the past few decades. The learners who are exposed to DI strategies showed enhanced selfconfidence (Affholder, 2003), increased motivation and engagement (Chien, 2012; Danzi, Reul \& Smith, 2008; Powers, 2008; Ramos \& Lasaten, 2018), and positive attitude (Baumgartner, Lipowski, \& Rush, 2003; Karadağ \& Yaşar, 2010; Liao, 2015), as measured by mixed data collection tools.

The impact of DI on learner achievement was also explored in the previous research. Baumgartner et al. (2003), found increased reading performance among primary and secondary school learners after being exposed to DI through flexible grouping, choices, longer self-selected reading time, and access to different reading sources. Similarly, Koeze (2007) reached increased reading achievement scores after implementing choice and interest strategies among fourth and fifth graders in Michigan; Beecher and Sweeny (2008) attempted to close the achievement gap among ethnically, culturally and economically diverse groups through enrichment program and DI. They found that engagement in learning was improved and the achievement gap reduced when elementary learners' interests and choices were taken into account. 
However, studies conducted in the field of ELT are limited. Chien (2012) found more improved and effective learning after modifying pre-assigned resources, offering learners choices, assigning them various activities, and varying the assessment tools complied with L2 learners in a Taiwanese elementary school. Similarly, Alavinia and Farhady (2012) reached raised vocabulary achievement score among 80 Iranian English learners after addressing learners' multiple intelligences. Aliakbari and Haghighi (2014) also found a significant difference after fostering reading comprehension through tiered instruction in content, process, and product. Recently, Siddiqui and Alghamdi's (2017) study resulted in a significant difference following applying tiered activities and flexible grouping at the L2 remedial hours of a university's preparatory program in Saudi Arabia with the participation of 17 learners and 4 teachers. Paredes (2017) experimented DI strategies like double entry journal, reading charts, project menus in compliance with 43 university learners' interests and needs to gauge their impact on learners' EFL vocabulary, reading, and grammar achievement. The findings revealed that the experimented strategies made a difference on the stated areas of L2 students.

The previous research also investigated teacher perceptions of DI. Teachers consider DI as time-consuming (Siam \& Al-Natour, 2016; Theisen, 2002), requiring professional training (Lunsford, 2017; Robinson et al., 2014; Siam \& Al-Natour, 2016) and necessitating in-depth knowledge about learner characteristics (Oliver, 2016).

Considering the existing evidence, namely the necessity of catering to learner differences and the lack in the scrutiny of execution of DI specifically stimulated the present study to contribute to the field with a model by seeking the impact of DI on high school L2 learners.

\section{Method}

The current study is based on an experimental design, and integrated both quantitative and qualitative data collection instruments. It aimed to investigate the impact of DI on high school learners' L2 achievement as well as explore their and the teacher researcher's perceptions of DI. In conjunction with the stated goals, the following research questions were addressed.

1. Is there a difference between DI group and control group regarding their L2 achievement?

2. What are the L2 learners' perceptions about DI?

3. What are the teacher researcher's perceptions about DI?

\subsection{Context and participants}

The study was carried out at a private high school in Istanbul, Turkey. The school delivers education to 545 students aged 16-19. The overwhelming majority of the population is Turkish despite having limited number of foreign students from different countries. The school requires all the sections from 9 th to 11 th grade to take 
an English placement test at the beginning of academic year, by which aiming to place students at the appropriate level ranging from A2 to $\mathrm{C} 1$ for the English Language Teaching program. Following the placement test, each grade is split into three CEFR levels according to the results such as ninth graders A2, B1 and B2.

The program intends to develop students' macro skills by offering them levelappropriate L2 program and thus graduate them with essential language communication skills. To this end, certain ELT coursebooks which are selected by a consultation committee before the onset of the academic year are assigned to the levels, and the ELT teachers are to cover the syllabi of these textbooks without diverging from the curricular goals of the program. Moreover, they are supposed to follow the procedural flow of the textbooks with a limited flexibility to adapt the book aligned with learner differences in terms of readiness, interest, learning styles and the other dynamic factors.

Concerning the assessment and evaluation of the program, the examination is administered over a common exam paper at the same time across the sister high schools. It thus forces educational staff of one campus to move along congruously with the other campuses. Having a standardized English program in each high school, as well as KG, primary and middle school, the institution gives little autonomy to its teachers to modify the program for learners' sake, which suggests that DI concerning content, process and product is nearly impossible unless it is specified in the unit plans. Yet, consent was given for two 9th grade classes only for research purposes and for a limited period.

The participants of the study were two intact 9 th grade classes with a total number of 22 students aged 15-17 studying at the elementary level (A2, CEFR) in the English program. Selection was made based on convenience sampling after taking administrative and parental consents. The students were placed at this level after a placement test administered at the start of the school year. The evaluation was made only upon the number of correct answers without including other criteria such as overall school achievement and a nation-wide high school entrance test score. The control group consisted of fourteen students, whereas the experimental group consisted of eight students. Detailed information about participants is displayed on Table 1 which indicates the overview of pre-assessment results, namely Perceptual Learning Style Preference Questionnaire (hereinafter PLSPQ) developed by Reid (1984), Holland Codes or Holland Occupational Themes (Holland, 1997) and teacher observation. The instructor of the control group was a colleague of the researcher who had been teaching since 2015, while the instructor of the experimental group was the researcher who had been teaching since 2009. Each group had weekly 8 hours of English each lasting 40 minutes. During the research, the experimental group received 6 hours of treatment (in total 24 hours) per week. 
Table 1. Participants

\begin{tabular}{|c|c|c|c|c|c|}
\hline Student & $\begin{array}{l}\text { Language } \\
\text { Background }\end{array}$ & $\begin{array}{l}\text { Learning Style } \\
\text { (Reid, 1984) }\end{array}$ & Interest & $\begin{array}{l}\text { Career } \\
\text { Dispositions } \\
\text { (Holland, 1997) }\end{array}$ & $\begin{array}{l}\text { Classroom } \\
\text { Behavior }\end{array}$ \\
\hline 1 & $\begin{array}{l}\text { Relatively better } \\
\text { command due to his } \\
\text { undertaking robust } \\
\text { pre-8 English in } \\
\text { China. }\end{array}$ & $\begin{array}{l}\text { Major- Auditory } \\
\text { Minor- Individual }\end{array}$ & $\begin{array}{l}\text { Football, } \\
\text { technology, } \\
\text { comparing } \\
\text { Chinese and } \\
\text { Turkish cultures }\end{array}$ & $\begin{array}{l}\text { Social jobs where } \\
\text { he solves } \\
\text { problems and } \\
\text { works in } \\
\text { cooperation }\end{array}$ & $\begin{array}{l}\text { Likes working in } \\
\text { groups and } \\
\text { helping others }\end{array}$ \\
\hline 2 & $\begin{array}{l}\text { Fairly good } \\
\text { command, likely } \\
\text { due to the intensive } \\
\text { English program in } \\
\text { his early education }\end{array}$ & $\begin{array}{l}\text { Major- Tactile } \\
\text { and Auditory } \\
\text { Minor- Individual }\end{array}$ & $\begin{array}{l}\text { Cooking, } \\
\text { photography }\end{array}$ & $\begin{array}{l}\text { Social jobs where } \\
\text { he interacts with } \\
\text { people and solve } \\
\text { their problems }\end{array}$ & $\begin{array}{l}\text { Loves reading and } \\
\text { watching about } \\
\text { crime, patronizes } \\
\text { the others }\end{array}$ \\
\hline 3 & $\begin{array}{l}\text { Confident yet } \\
\text { ineffective English } \\
\text { despite 4-year-long } \\
\text { middle school } \\
\text { program }\end{array}$ & $\begin{array}{l}\text { Major- Group and } \\
\text { Kinesthetic } \\
\text { Minor- Individual }\end{array}$ & $\begin{array}{l}\text { Cooking, } \\
\text { videogames, } \\
\text { watersports }\end{array}$ & $\begin{array}{l}\text { Conventional } \\
\text { jobs, working } \\
\text { routinely as a } \\
\text { accountant, clerk }\end{array}$ & $\begin{array}{l}\text { Cooperative, } \\
\text { helpful, enjoys } \\
\text { competitive tasks }\end{array}$ \\
\hline 4 & $\begin{array}{l}\text { No prior experience } \\
\text { likely due to poor } \\
\text { state school } \\
\text { program }\end{array}$ & $\begin{array}{l}\text { Major- Auditory } \\
\text { and Group } \\
\text { Minor- Individual }\end{array}$ & $\begin{array}{l}\text { Media and } \\
\text { fashion }\end{array}$ & $\begin{array}{l}\text { Media, } \\
\text { enterprising fields }\end{array}$ & $\begin{array}{l}\text { Conscientious, } \\
\text { cooperative, yet } \\
\text { lacks self- } \\
\text { confidence }\end{array}$ \\
\hline 5 & $\begin{array}{l}\text { Poor command } \\
\text { despite early } \\
\text { education in France }\end{array}$ & $\begin{array}{l}\text { Major- Auditory } \\
\text { and Individual } \\
\text { Minor- Group and } \\
\text { visual }\end{array}$ & $\begin{array}{l}\text { Videogames, } \\
\text { computers }\end{array}$ & Engineer & $\begin{array}{l}\text { Rarely grasps } \\
\text { tasks or speaks, } \\
\text { prefers working } \\
\text { alone }\end{array}$ \\
\hline 6 & $\begin{array}{l}\text { Poor command of } \\
\text { English despite } \\
\text { intensive prior } \\
\text { English program }\end{array}$ & $\begin{array}{l}\text { Major- Individual } \\
\text { Minor- None } \\
\text { deduced from the } \\
\text { scale }\end{array}$ & $\begin{array}{l}\text { History and } \\
\text { Theology }\end{array}$ & $\begin{array}{l}\text { Social jobs such } \\
\text { as teacher, } \\
\text { psychologist, } \\
\text { counselor }\end{array}$ & $\begin{array}{l}\text { Alienated from } \\
\text { the class, learns } \\
\text { by writing, yet too } \\
\text { slowly }\end{array}$ \\
\hline 7 & $\begin{array}{l}\text { Very poor command } \\
\text { likely due to } \\
\text { inefficient state- } \\
\text { based program }\end{array}$ & $\begin{array}{l}\text { Major- Group and } \\
\text { visual } \\
\text { Minor- Auditory }\end{array}$ & Cinema, music & Actor & $\begin{array}{l}\text { Prefers pair-group } \\
\text { works, bullying } \\
\text { others }\end{array}$ \\
\hline 8 & $\begin{array}{l}\text { Very poor command } \\
\text { likely due to } \\
\text { irregular prior } \\
\text { experience }\end{array}$ & $\begin{array}{l}\text { Major-Kinesthetic } \\
\text { an Group } \\
\text { Minor-Individual }\end{array}$ & Computer & $\begin{array}{l}\text { Enterprising } \\
\text { occupations }\end{array}$ & $\begin{array}{l}\text { Inclusive student, } \\
\text { health problems } \\
\text { occasional no- } \\
\text { shows }\end{array}$ \\
\hline
\end{tabular}

The teacher researcher has been teaching English as a foreign language since 2009 to various groups of learners between the ages of 7 and 19 in Turkey. The researcher's interest area of research is primarily DI, curriculum development, and teacher education. Considering DI as the most essential solution for the current teaching context, he seeks expertise in the field of DI by experimenting various self-prepared lesson procedures in compliance with different DI strategies. The teacher researcher intended to contribute to this field with this study in which he used some preassessment surveys, implemented some DI strategies, and took some theoretical principles into account in the design of the DI lessons, which is given at length further in the paper.

\subsection{Data collection instruments}


The study incorporated multiple data collection phases to make sure that all the garnered data would be analyzed appropriately. PLSPQ and Holland Codes test were administered to assemble vital information about the participants before the treatment. With respect to the nature of the study, it relied heavily on the statistical analysis of the achievement test as a result of which the impact of the treatment on student L2 achievement was determined. Finally, with an intent to reach the effect of the experiment on the perception of the participants and the researcher, qualitative data was collected through reflective essays kept by the participants at the end of the study and reflective journals kept by the teacher researcher at the end of each treatment week.

\subsubsection{Perceptual learning style preference questionnaire}

The PLSPQ was developed by Joy Reid (1984) in an attempt to measure English language learners' preferred learning styles. It is made up of 30 self-reporting statements aiming to unveil six learning styles, namely auditory, group, individual, kinesthetic, tactile and visual based on a 5-point Likert scale from 1 (strongly disagree) to 5 (strongly agree). As a consequence of the calculation tendered by the scale, engendered learning styles are classified as major, minor and negligible. Major learning style denotes the preferred learning style, whilst minor learning style could still function in learning as opposed to negligible learning style indicating difficulty learning in that way (Reid, 1995). The rationale behind the selection of this instrument was not only its suitability for the context (English Language Learning) but also its conduciveness to garnering information about learners' preferred way of learning, which informed DI-based lesson plans.

\subsubsection{Holland codes}

Holland Codes or the abbreviation RIASEC, developed by John L. Holland (1997), represents a theory of personality in concern with career dispositions. The test categorizes people in terms of their inclination to six distinct groups of occupations, namely realistic, investigative, artistic, social, enterprising, and conventions, which is conventionally abbreviated as RIASEC. The test comprises 48 occupational tasks that are rated by how much it is relished on a scale of 1 (dislike) and 5 (enjoy). The test is available online and takes 5-10 minutes to complete. The incentive behind implementing this test was its feasibility for unearthing respondents' career dispositions and descriptions of the task they are predisposed to enjoy experiencing, as well as its practicality for providing information about learners' profile.

\subsubsection{Achievement test}

The achievement test was applied three times as pre-test, post-test, and delayed post-test in the study. It comprised reading, writing, vocabulary and grammar questions which were taken from the material pack of the level textbook. The test was the recommended end of unit test that had been prepared in parallel with the unit goals and content. Therefore, piloting was not considered to be necessary to measure its suitability (validity) to the level. The test was conducted to both groups prior to the 
treatment and lasted 60 minutes to complete. The same test was given to the participants as the post-test just after the treatment which lasted as long as four weeks, and as delayed post-test five weeks later. The reading section of the achievement test comprised ten questions. Five of these questions measured reading for main idea, whereas three of them measured reading for specific information, and two of them tested reading for detailed information sub-skills. The section constituted $25 \%$ of the total weight. Given writing section of the test, with $25 \%$ of total weight, it only had one task that required students to use target structures and words in a meaningful context. The pieces of students were assessed by two raters against the criteria given by the institution as suggested by Brown (2007). The quantitative data related to writing products of the control and experimental groups in pre-, post-, and delayed post-tests entailed a second rater for a reliable data analysis procedure. That being the case, the researcher requested a colleague of his, who holds a BA and MA degree in English Language Teaching, and has been teaching since 2009, to grade the writing pieces of both groups. Following the Cohen's Kappa calculation, a strong agreement between two raters in the pre-test $(\mathrm{k}=0.95)$, in the posttest $(\mathrm{k}=0.94)$, and in the delayed post-test $(\mathrm{k}=0.89)$ was found. Concerning vocabulary section, it was composed of 25 items each having one point of value, thus making up $25 \%$ of the total score. The type of vocabulary ranged from main verbs (15 items) to target nouns (10 items). Finally, the grammar section included 18 question items. Seven items gauged the ability of using possessive have in the correct form, while five items asked for distinguishing possessive "have" and present "to be". Last six items tested the ability of putting "can" in the correct form in a dialogue. The section constituted the final $25 \%$ of the overall score.

In the present study, the researcher controlled the measurement of instruments as a source of error. In addition to this, the procedure of scoring was objective and clearcut, as the publishing company had already prepared the answer key of the test, which had single correct answer. For the writing pieces of the participants, an experienced ELT teacher graded the writings of the participants for more reliable interpretation. Moreover, the test was not brief but long enough to measure specific skills of the students efficiently, which also contributed to the reliability of the study. Furthermore, the achievement test was retaken five weeks after the post-test, which also increased the reliability of the study. When it comes to the Cronbach's alpha value of the study, it was .831 which confirmed the reliability and internal consistency of the test.

\subsubsection{Reflective essays}

Reflective essays illustrate one's perceptions, attitudes, understanding, thoughts and reactions upon some experience or on a subject matter. This study thus made use of reflective essays in order to reach the perceptions of the participants who experienced the treatment. The essays were written by all the students in the DI group. The students reflected on the treatment they had been exposed to for a month. The essays of the participants provided data for the second research question. 
Following exploratory analysis of the essays to obtain a general sense of data (Creswell, 2012) in-depth coding process was conducted. During open coding, major categories (themes) related to the DI were identified. Specifically, major themes in concern with the participants' perceptions of DI were determined. As the study included open coding, the inter-rater reliability was sought for a true interpretation of the results. The inter-rater reliability means that "two or more individuals observe an individual's behavior and record scores, and then the scores of the observers are compared to determine whether they are similar" (Creswell, 2012, p. 622). To find out the inter-rater reliability, two expert ELT teachers determined major categories out of the codes. For this study, the formula proposed by Miles and Huberman (1994), assuming $80 \%$ agreement sufficient, was performed. Consequently, the inter-rater reliability was found $90 \%$, which is above the satisfactory rate.

\subsubsection{Reflective journals}

A reflective journal is an account of a work in progress, which helps researcher reflect on the experience (Creswell, 2012). In this study, this data instrument was employed to explore the teacher's attitudes during the planning and preparation of differentiated lesson plans, and after the implementation, which provided data for the last research question.

\subsection{Data Collection Procedure}

The study lasted for nine weeks including four weeks of treatment. In the first week, the researcher collected data about DI group's interests, learning styles, and profile in order to acquaint himself with them and design informed lessons. To this end, two pre-assessment tests; PLSPQ developed by Reid (1984) and Holland Codes (Holland, 1997) were conducted to better familiarize himself with learners, particularly about learners' characteristics, learning styles and career dispositions, which later, along with the teacher researcher's observation notes, formed DI-based lessons,. After having a good knowledge of the learners, the researcher conducted achievement test in both groups to determine readiness in the second week.

Then, in the following four weeks, the teacher of the DI group abode by the content of the textbook as mandated by the school's ELT department but modified the process and product by harnessing the conceptual framework of constructivism. Specifically, he entailed from learners to engage in learning environment, to connect the input to their real-life and existing experience, and most importantly to build knowledge through interacting with peers and other people in an attempt to construct meaning of the given input. Additionally, he differentiated the process by taking the advice of Vygotsky (1978) in that it included activities that were just above the current level of students, (the zone of proximal development), thus challenging them to reach the lesson goals by constructing new knowledge stage by stage. In concern with his role, the teacher, as is also assumed in the constructivist theory, took on the role of facilitator who not only diagnosed the needs, abilities, interests, and learning styles of learners but also helped them construct meaning through appropriately designed 
lesson plans as supported by DI strategies. Table 2 illustrates the theoretical and practical groundwork of the study, which is recommended for an informed DI.

Table 2. Theoretical and practical groundwork

\begin{tabular}{ll}
\hline Framework & Function \\
\hline PLSPQ & To inform about learners' preferred learning styles \\
Holland Codes & To inform about learners' career dispositions \\
Observation & To inform about learners' classroom behaviors and their learning profile \\
Constructivism & To liaise knowledge with the real life \\
The ZPD & To build on current knowledge or skills through challenging activities \\
DI Framework & To guide instruction through its conceptual propositions and hands-on strategies \\
Multiple Intelligence & To inform instruction as regards task variation
\end{tabular}

The teacher researcher also differentiated the ways of production that the students would likely to prefer. In other words, lessons were designed, as underpinned by multiple intelligence theory, (Gardner, 2008, as cited in Paone, 2017) bearing diverse dominant intelligences among the class instead of expecting a shared type of from learners. Furthermore, he used DI strategies, as suggested by Tomlinson (1999) such as tiered-activities used to design materials in line with the readiness of the participants; choices used to provide learners with alternative tasks in relation to their interests and real life, and to give them the liberty of opting for any of them; flexible grouping used to group learners differently not only in compliance with their learning styles (e.g. individual learner, group learner) but also with their interests (e.g. the ones interested in photography), as reported in the PLSPQ and Holland Codes results. Table 3 exhibits a brief lesson procedure (practical implementation) of Week 3.

In the following two weeks both groups took the achievement test immediately and five weeks after the instruction; DI group wrote their reflective essays and the teacher researcher collected his weekly written reflective journals. In the last week (Week 9), the researcher analyzed both quantitative and qualitative data. The overview of the procedure is illustrated on Table 4. 
Table 3. Example Procedure (Week 3)

\begin{tabular}{|c|c|c|c|}
\hline Group & Aim & Procedure & Strategies \\
\hline Control & $\begin{array}{l}\text { Describe } \\
\text { people using } \\
\text { have in the } \\
\text { affirmative } \\
\text { form }\end{array}$ & $\begin{array}{l}\text { Reading for detailed information } \\
\text { Listening for specific information in the context of clothing } \\
\text { Introducing lexical sets of colors and clothes } \\
\text { Speaking and writing activities based on textbook characters } \\
\text { Homework assignment from Workbook } \\
\text { Source: New Inspiration } 1 \text { Student Book (Garton-Sprenger \& } \\
\text { Prowse, } 2011 \text {, pages } 24 \text { and } 25 \text { ) }\end{array}$ & $\begin{array}{l}\text { Traditional } \\
\text { instruction that } \\
\text { assumes almost full } \\
\text { dependence on the } \\
\text { textbook with very } \\
\text { little flexibility to } \\
\text { ensure } \\
\text { standardization }\end{array}$ \\
\hline \multirow[t]{9}{*}{ DI } & $\begin{array}{l}\text { Describe } \\
\text { people using } \\
\text { have in } \\
\text { affirmative } \\
\text { and the } \\
\text { other forms }\end{array}$ & $\begin{array}{l}\text { Conversational worksheet on what hobbies do they have, what } \\
\text { do they have that most people do not have (St-1, auditory, } \\
\text { above the average level, and St-2, auditory and above the } \\
\text { average level). These two students with similar preferred } \\
\text { learning style and level found their commonalities. The rest of } \\
\text { the class followed the textbook sections }\end{array}$ & Flexible grouping \\
\hline & & $\begin{array}{l}\text { Find someone who... in the context of expressing possession } \\
\text { (The rest of the class) }\end{array}$ & Tiered activities \\
\hline & & $\begin{array}{l}\text { St-1 \& St-2 prepared a text related to the result of their } \\
\text { exchange of information using conjunctions and, but. }\end{array}$ & \\
\hline & & $\begin{array}{l}\text { Describe and identify famous people using have/has in pairs } \\
\text { (Additional activity for the whole class) }\end{array}$ & \\
\hline & & Write a paragraph describing family members (St-4-5-6-7-8) & Choice \\
\hline & & $\begin{array}{l}\text { Write a paragraph describing two celebrities comparatively (St- } \\
1-2-3)\end{array}$ & \\
\hline & & Homework & \\
\hline & & $\begin{array}{l}\text { Auditory (St-1-2-4-5) and group learners (St-3-7-8) prepare } 10 \\
\text { questions using possessive have in the context of clothing, and } \\
\text { interview one person from the family or friends. }\end{array}$ & Choice \\
\hline & & $\begin{array}{l}\text { At the end of the interview the students were supposed to } \\
\text { either prepare a chart about the wardrobe of the interviewed } \\
\text { person or a video showing the person's clothing style }\end{array}$ & \\
\hline
\end{tabular}

Table 4. Overview of data collection procedure

\begin{tabular}{ll}
\hline Week & Procedure \\
\hline Week 1 & Observation, Perceptual Learning Style \\
& Preference Questionnaire, Holland Codes \\
Week 2 & Pre-test \\
Week 3 & Treatment, Reflective Journal \\
Week 4 & Treatment, Reflective Journal \\
Week 5 & Treatment, Reflective Journal \\
Week 6 & Treatment, Reflective Journal \\
Week 7 & Post-test \\
Week 8 & Delayed post-test \\
Week 9 & Reflective essays \\
\hline
\end{tabular}

\subsection{Data Analysis}

Non-parametric tests were run since the size was not big enough in control and experimental groups. Quantitative data were processed and analyzed through SPSS 
(Statistical Package for the Social Sciences) version 22. Raw data out of student reflective essays and teacher reflective journals were analyzed inductively (Boyatzis, 1998), for there were no pre-determined categories to seek. With an explorative approach, the codes were identified using open coding, they were then categorized, which was followed by thematic analysis. The emerging codes and themes were iteratively verified in an attempt to make meaningful interpretations (Creswell, 2012).

\section{Results}

Aligned with the three research questions, this section is split into three subsections. The first subsection presents an overview of the achievement scores of both groups, while the other two sections give account of the inductive analysis of the reflection papers and reflective journals.

\subsection{Achievement rates}

Overall scores of each group were measured after each testing attempt using Friedman test (Table 5).

Table 5. Overall scores (Friedman test)

\begin{tabular}{|c|c|c|c|c|c|c|c|c|c|c|c|c|}
\hline \multicolumn{5}{|c|}{ Experimental } & \multicolumn{8}{|c|}{ Control } \\
\hline Item & $\mathrm{M}$ & $\mathrm{SD}$ & Min & $\operatorname{Max}$ & $\mathrm{df}$ & $\mathrm{p}$ & $\mathrm{M}$ & SD & Min & $\operatorname{Max}$ & $\mathrm{df}$ & $\mathrm{p}$ \\
\hline Pre-test & 35.7 & 18.15 & 13 & 60 & & & 36.9 & 15 & 10 & 63 & & \\
\hline Post-test & 67 & 17 & 41 & 90 & 2 & 0.002 & 49.4 & 15.3 & 25 & 80 & 2 & 0.000 \\
\hline Delayedpost-test & 68.1 & 18.3 & 41 & 92 & & & 48.1 & 12.6 & 30 & 77 & & \\
\hline
\end{tabular}

The experimental group's scores are respectively $\left(\mu_{1}=35.75, \mu_{2}=67.25, \mu_{3}=68.13\right)$ which indicated that the experimental group almost doubled the score after the treatment. It is concluded that the treatment made a difference on DI group's overall achievement. The delayed post-test test was implemented five weeks after the posttest, and the result showed no significant difference as compared to the post-test. The control group's overall scores are respectively $\left(\mu_{1}=36.93, \mu_{2}=49.43, \mu_{3}=48.14\right)$ which showed around 13\% increase from pre- to post-test. Once the delayed post-test scores were calculated, the result showed no difference comparing to the post-test. The effect size for this analysis $(d=1.06)$ was found to exceed Cohen's (1988) convention for a large effect size.

Wilcoxon Signed Rank Test (Table 6) was operated to identify the groups posing difference. As multiple comparisons were required to be made on the same data, the significance level was taken as $=.05 / 3=.0167$ (Bonferonni correction). 
Table 6. Overall results (Wilcoxon Signed Rank)

\begin{tabular}{lllll}
\hline \multirow{2}{*}{ Group } & & $\begin{array}{l}\text { Post_overall }- \\
\text { Pre_overall }\end{array}$ & $\begin{array}{l}\text { Delayed_overall }- \\
\text { Pre_overall }\end{array}$ & $\begin{array}{l}\text { Delayed_overall }- \\
\text { Post_overall }\end{array}$ \\
\hline \multirow{3}{*}{ Experimental } & $\mathrm{Z}$ & $-2.533 \mathrm{~b}$ & $-2.524 \mathrm{~b}$ & $-.254 \mathrm{~b}$ \\
& Asymp, Sig, (2-tailed) & 0.0110 & 0.0120 & 0.7990 \\
& Asymp, Sig, (1-tailed) & 0.0055 & 0.0060 & 0.3995 \\
\hline \multirow{3}{*}{ Control } & $\mathrm{Z}$ & $-3.297 \mathrm{~b}$ & $-2.626 \mathrm{~b}$ & $-.770 \mathrm{c}$ \\
& Asymp, Sig, (2-tailed) & 0.0010 & 0.0090 & 0.4410 \\
\hline
\end{tabular}

a. Wilcoxon Signed Ranks Test.

b. Based on negative ranks.

c. Based on positive ranks.

When Table 6 is viewed, there is a statistically significant difference between preand post-test overall scores $(\mathrm{z}=-2.533, \mathrm{p}=.006<.0167)$ in the experimental group, which denotes that the treatment made a significant difference by leading to an increase in the overall scores. A significant difference is also true between pre- and delayed posttest $(\mathrm{z}=-2.524, \mathrm{p}=.006<.0167)$. Regarding the difference between post- and delayed post-test, there is not a significant difference in terms of overall achievement $(\mathrm{z}=-.254$, $\mathrm{p}=.399>.0167)$.

Given the control group, there is a statistically significant difference between posttest and pre-test overall scores $(z=3.297, \mathrm{p}=000<.0167)$. In other words, the traditional instruction made a significant difference by leading to an increase in the overall scores. A significant difference is also true between pre- and delayed post-test ( $\mathrm{z}=$ 2.626, $\mathrm{p}=.004<.0167)$. Regarding the difference between post- and delayed post-test, there is not a significant difference in terms of overall achievement $(\mathrm{z}=-.770$, $\mathrm{p}=.221>.0167)$.

The study's first research goal was to investigate the achievement difference between the DI group and the control group. Table 7 depicts both groups' overall achievements.

Table 7. Overall achievement (Mann-Whitney U)

\begin{tabular}{|c|c|c|c|c|c|c|c|c|}
\hline Design & Item & Group & $\mathrm{N}$ & $\mathrm{M}$ & SD & $\mathrm{MR}$ & $\mathrm{z}$ & Sig. \\
\hline \multirow{2}{*}{$\begin{array}{l}\text { Pre-Post } \\
\text { Test }\end{array}$} & \multirow{2}{*}{ Overall } & Exp. & 8 & 31.50 & 11.68 & 18.13 & \multirow{2}{*}{-3.624} & \multirow{2}{*}{0.000} \\
\hline & & Cont. & 14 & 12.50 & 5.93 & 7.71 & & \\
\hline \multirow{2}{*}{$\begin{array}{l}\text { Post-Del. } \\
\text { Post Test }\end{array}$} & \multirow{2}{*}{ Overall } & Exp. & 8 & 0.88 & 6.77 & 13.25 & \multirow{2}{*}{-.959} & \multirow{2}{*}{0.338} \\
\hline & & Cont. & 14 & -1.29 & 11.73 & 10.50 & & \\
\hline
\end{tabular}

Regarding overall achievement, the increase after treatment is 31.5 points in the experimental group, and 12.5 points in the control group, which poses a statistically significant difference $(\mathrm{z}=-3.624, \mathrm{p}=0.000<.05)$ between the groups. Moreover, there is 0.88 points overall increase from post- to the delayed post-test in the experimental group, while there is -1.29 points decrease in the control group. When the difference is analyzed between these two groups $(\mathrm{z}=-.959, \mathrm{p}=0.338>05)$, no significant difference is 
found between the groups. To have a better insight into the achievement, Table 8 dissects the achievement score based on reading, writing, vocabulary and grammar sections.

Table 8. The breakdown of achievement

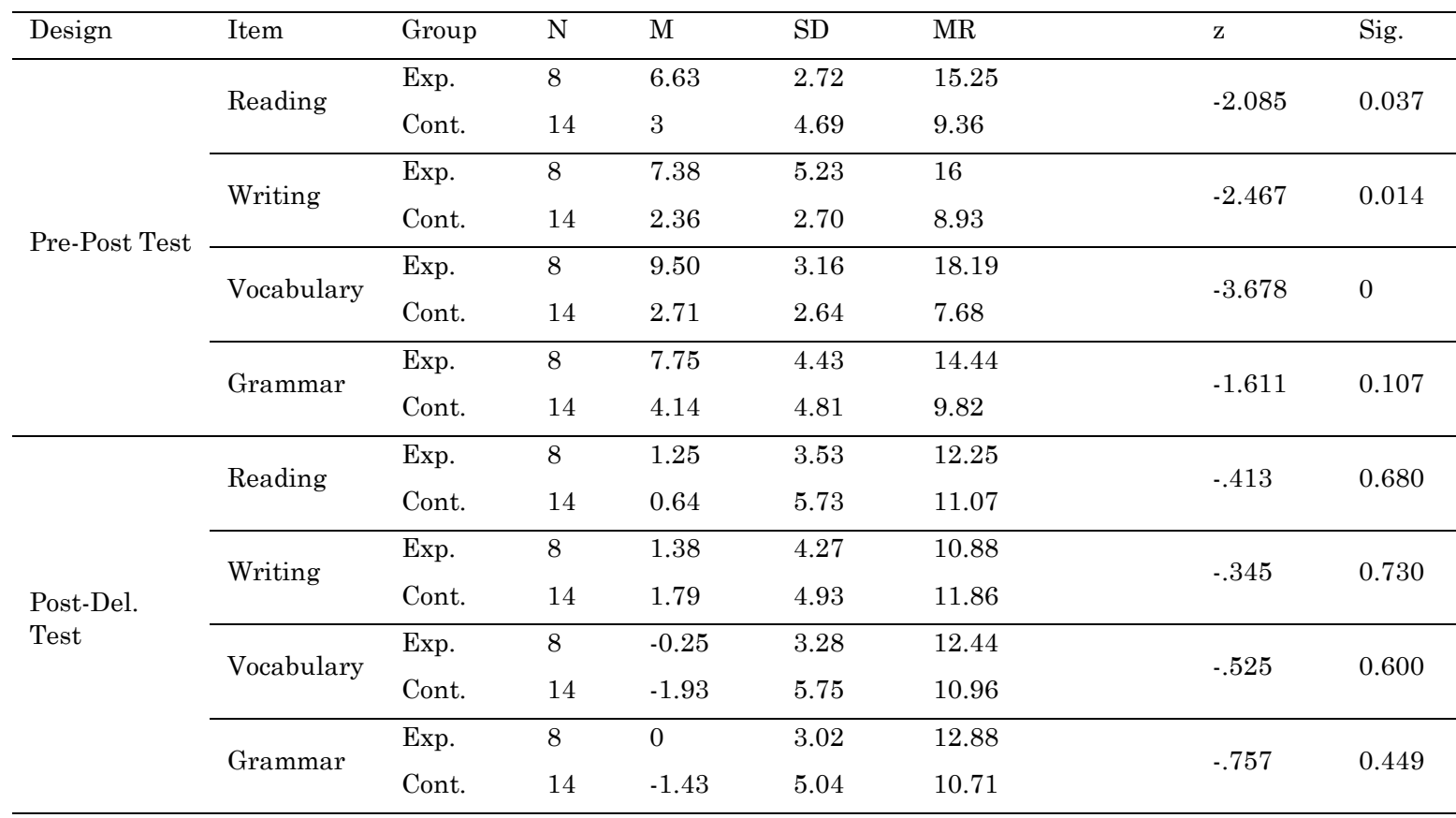

Table 8 demonstrates that while the increase is up to 6.63 points in the experimental group, it is 3 points in the control group, which poses a significant difference $(\mathrm{z}=2.085, \mathrm{p}=0.037<.05)$ between the groups in terms of reading achievement. When the writing difference is analyzed between the groups $(\mathrm{z}=-2.467$, $\mathrm{p}=0.014<.05$ ), there is a statistically significant difference between the groups in terms of writing achievement. It also shows that there is a statistically significant difference $(\mathrm{z}=-3.678, \mathrm{p}=0.000<.05)$ between the groups concerning vocabulary achievement. Given grammar achievement, unlike the previous measurements there is not a significant difference $(\mathrm{z}=-1.611, \mathrm{p}=0.107>.05)$ between the groups.

\subsection{Results of the Reflective Essays}

An in-depth analysis of students' reflective essays yielded eight codes that were grouped into two main themes (Table 9).

Table 9. Thematic coding (Reflective essays)

\begin{tabular}{ll}
\hline Main themes & Codes \\
\hline Positive Attitude & Entertaining, engaging, instructive \\
Unorthodox Aspects & Various activities (e.g. presentations, questionnaires) lack of full adherence to \\
& textbooks, right to choose, peer aid, interest-related tasks \\
\hline
\end{tabular}


Basically, participants expressed their content with the treatment with respect to its being entertaining, engaging and instructive, all of which were categorized as positive attitude.

[...] I had such entertaining lessons that sometimes I did not take a break because I was engaged in the tasks. In the previous lessons. I was not this engaged. (S5)

[...] I easily learnt about grammar topics and words. I did not have any difficulties to understand them because we did several practices. (S2)

Based on the comments, it can be inferred that differentiating L2 instruction resulted in not only fun and entertainment but also engagement and learning.

The participants also stated that the treatment brought unconventional aspects such as preparing presentations and questionnaires, not fully covering the textbook, giving students the liberty of choosing among optional activities, getting help from peers and having interest-related tasks.

[...] It was a different experience for me because we used to cover the textbook before this. (S6)

[...] We were offered to choose among different tasks. I enjoyed preparing a recipe for "Patlican Kebabl", and Dos and Dont's of photography. (S2)

[...] I did not use to work with a classmate very often, but in these lessons, I generally worked with them to prepare a questionnaire, to get their help about preparing a presentation and so forth. It was very useful. (S5)

Based on the comments it is deduced that DI is viewed unconventional in many aspects such as the variety, flexibility and grouping of the activities, which was barely or never experienced in the traditional instruction.

\subsection{Results of the Reflective Journals}

An in-depth inductive look into the journals unveiled five codes that fell into two main themes (Table 10)

Table 10. Thematic coding (Reflective journals)

\begin{tabular}{ll}
\hline Main themes & Codes \\
\hline Challenges & Time consuming, lack of autonomy \\
Familiarity & Student profile (e.g. learning styles, interests etc.), student differences, \\
& planning and implementing DI \\
\hline
\end{tabular}

The recurring patterns were mainly based on the challenges, specifically that DI be time consuming and the practitioner be unable to bend institutional regulations and rules.

[...] I cannot help thinking how I could deal with DI if it were required by the school, because it took all my weekend to prepare for one class. (T, Treatment Week 2) 
[...] If I did not have to adhere to the textbook, it would be easier to differentiate. Textbook constrained me to include target language and unit goals. ( $\mathrm{T}$, Treatment Week 2)

[...] I had to cover certain parts of the book at times, as it was required by the foreign languages department to conduct the same exams across two campuses, which rather affected the efficiency of the study. (T, Treatment Week 3)

These statements vividly indicate that planning and preparation for DI was timeconsuming and nearly unmanageable because of the regular school responsibilities such as lesson plans, paperwork, and administrative burdens. Such being the case, it can be inferred that planning and preparing DI require a great deal of time, or else it is highly likely to be obstructed by time-constraints. The comments also emphasize that DI was impeded from a complete implementation due to institutional policies. This challenge of the researcher implies the issue of strict policies in the schools in which teachers neither have flexibility to modify syllabus nor are given autonomy to differentiate instruction for the optimization of learning. In other words, schools do not allow their teachers to change instruction for the sake of establishing standard instruction across multiple campuses.

The analysis of the reflective journals also revealed the fact that DI necessitates multilayered familiarity, particularly with learner diversities, learning styles, interests and teacher knowledge of planning and implementing DI.

[...] Although I applied the PLSPQ and Holland Codes to get to know their preferred learning styles, strong intelligences, and occupational orientations, I had to make observations to become more aware of my learners. (T, Preassessment Week 1)

[...] I was overwhelmed while putting thought on how to cater to varieties and follow the curricular objectives at the same time. I need to improve myself in this area. (T, Treatment Week 4)

The records of the teacher demonstrate that differentiating instruction called for a full awareness of learners in concern with not only their learning characteristics but also individual tendencies, interests, and so forth. Therefore, it can be concluded that DI starts with knowing learners' academic, and social varieties, as a result of which instruction can be effectively differentiated based on these varieties. The expressions of the teacher also highlight the fact that DI involved some degree of knowledge about the treatment to overcome the obstacles related to integrating DI tools into the present curriculum. This challenge of the teacher brings the issue of professional development to the light, as DI does not simply assume finding extra sources for the program; rather it conforms developed and adapted materials to learner varieties, which varies from context to context. 


\section{Discussion}

The research sought to determine whether there was a difference in learners' overall L2 achievement including reading, writing, vocabulary, and grammar scores from pre- to post-test. The results demonstrated a significant difference between the scores of two tests both in control and DI groups, which suggests that both traditional instruction and DI gave rise to an increment in students' L2 overall achievement. However, concerning comparative results, it was found that the difference is higher in DI group than control group.

The reason to that is most probably due to DI's learner-centered approach that assumes and accepts students as individuals with diverse abilities, needs, interests, learning styles, and preferences. Conversely, traditional instruction bears whole-class delivery with little diversity but full commitment to the syllabus of the textbook. In other words, it is more teacher-centered in that it offers a standard teaching that is carried out nearly in the same way among practitioners. Simply put, traditional instruction did not surpass the impact of DI because it was applied irrespective of learner idiosyncrasies in the classroom.

Another reason that DI resulted in better scores might be due to the fact that the instruction embodies such DI strategies as tiered activities, choices, and flexible grouping. With tiered activities, the researcher assumed the mixed levels and abilities of the students by designing or redesigning materials in concert with learners' readiness and abilities over the same unit goals. For instance, some learners worked on preparing and conducting a new questionnaire on life skills, while the others conducted a ready-made questionnaire after making sense of the questionnaire items, which allowed all learners to reach the equal unit goals through level-appropriate tasks. This finding concurs with the study of Chien (2012) who reached similar outcomes through the previously mentioned strategies in an elementary school's EFL class in Taiwan, and with Siddiqui and Alghamdi (2017) whose study generated very similar results at the L2 remedial hours of a preparatory program in Saudi university.

Ultimately, incorporation of interest-relevant materials might be the other reason for the difference. Taking interests of learners into account led to a conducive learning environment in which the learners relished studying. This outcome is in line with the findings of Beecher and Sweeny (2008) who also found increased achievement scores after considering learners' interests in their longitudinal study conducted at an elementary school in the USA. Since limited research is available in L2 setting, there is still a need for further investigation into the impact of DI strategies.

The other research question aimed to look into the impact of DI on learners' perceptions, as interpreted from qualitative data obtained from reflective essays kept by the students in the DI group at the end of the study. Given the overall results, it can be stated that DI through the strategies of tiered activities, flexible grouping, and choices which were suited to learners' readiness and interests engendered a positive attitude. One reason to that is most probably that the learners' interests (e.g. St-2's 
interest in cooking and photography, St-7's interest in cinema) were considered during the preparation of DI, which corresponds with the result of Danzi et al. (2008) who also found increased motivation and decreased boredom in their study with primary and middle school learners. The other reason to such a result might be due to the unconventional instruction in which learner's mixed readiness levels were respected, and coped with through tiered activities, which is in agreement with Karadağ and Yaşar (2010), whose study revealed that such DI strategies affected students' attitude in a positive way among middle school Turkish learners. By the same token, Chien (2012) measured the impact of tiered tasks, and found boosted learner motivation, and joy among a Taiwanese elementary school's EFL learners. Moreover, the findings are in line with Liao (2015) who uncovered that such tasks had positive influence on learner perception at a Taiwanese university's EFL classes. The final reason is probably the consideration of varied learning styles in DI groups as informed by the results of PLSPQ test, which was also found effective in Ramos and Lasaten (2018). However, it should be noted that it is almost impossible to address each learner's individual interests, abilities, and learning styles especially in larger groups. Therefore, the size of the class was the reason that encouraged the teacher to offer diverse interest-relevant tasks. Yet, it is likely to diversify existing materials in the way that are tailored to mixed learning profiles in general if not peculiar to individuals.

The objective of the final research question was to elucidate the perceptions of the teacher researcher about the implementation of DI, as extracted and interpreted from the recurring themes in the reflective journals weekly kept by the teacher. The overall results of data analysis suggested that implementation of DI posed many a challenge such as keeping up with school schedule and DI at the same time, being conscious about the learners, knowing how to differentiate, and meeting institutional curricular requirements. The first and foremost difficulty for the teacher was to maintain DI and the regular workload at the same time. In other words, the most significant issue is time constraints. The necessity for more time is generally induced by the amount of regular workload of teachers including lesson plans, documentations, paperwork, and meetings. This issue is also agreed by Theisen (2002) in which teachers expressed their concern, and difficulty about the lack of time; Robinson et al. (2014) who also found lack of adequate time among many other challenges of teachers, as well as Oliver (2016), and Siam and Al-Natour (2016), all of whom reached the same conclusion. The other recurring theme found in the reflective journals was the indispensability of being informed about learner profile, by which the researcher drew attention to the becoming aware of learners' needs, abilities, profiles, interests, strengths, weaknesses and the other characteristics. This finding also aligns with Oliver (2016) in which the participants reported their trouble knowing and meeting the needs and abilities of learners. The other major theme was the necessity of familiarity with planning and carrying out DI, which recommends that professional development and training are required to be able to differentiate instruction effectively, which concurs with the findings of Oliver (2016), and Lunsford (2017). 
This finding uncovers the fact that differentiation of instruction is not an easy job such as taking attendance and managing classroom that can be achievable by every incumbent teacher. On the contrary, it entails in-depth knowledge about the principles of DI, in which institutions need to prioritize as a need of teachers to cater to immediately if DI is of high importance to the school. In brief, apart from the expected difficulties of DI like time constraints, professional development, the perspectives of institutions in standardization, giving flexibility to teachers constitute a significant issue in front of teachers, and make DI even harder.

\section{Conclusions}

The present research study intended to find out whether DI resulted in a significant difference in L2 achievement of Turkish high school students, and explore the students' perceptions about DI and the teacher's perception about planning and implementing DI. Quantitative findings displayed that DI makes a difference in L2 achievement among Turkish high school learners as measured by an achievement test. Qualitative data analysis displayed that investigating student perceptions generate valuable data for teachers who plan to execute DI in their classroom. Similarly, findings from teacher journals generated important ideas and issues in the field of DI.

The study has several recommendations for future research in the field of DI. The recommendations are presented firstly through the lens of English language teaching practitioner and then researcher. First and foremost, it should be noted that DI is not a teaching method nor a range of strategies but an approach to teaching and a way of thinking. To elaborate, DI does not have strict boundaries that limit teachers to carry out specific strategies in specific ways. Conversely, it offers a mindset that expects to become aware of learner varieties in needs, abilities, interests, learning styles, and intelligence in class, thus entailing to prepare lessons in response to the existing varieties. Briefly, it is a teaching approach that considers student differences, and assumes learner-focused and tailored instruction in accordance with varied learner characteristics.

Secondly, it is recommended for teachers, who intend to enact DI, especially in large classes, to administer pre-assessment tools and make preliminary observation about how their learners learn, and what their interests, strengths and weaknesses are. It is paramount to get to know more about learners, which yield valuable data that inform the implementation of DI. After getting the results from pre-assessment tools, teachers could group learners in terms of their readiness, preferred learning styles, and interests. In so doing, teachers could design lessons in alignment with general characteristics of learners, rather than trying to cater to every single variety in the class, which is not a part of DI. In brief, one should note that DI is not individualized instruction.

Thirdly, DI encompasses a broad spectrum of strategies, areas, and theoretical assumptions, which might deter language teachers from trying it in their classes. 
However, teachers should not be daunted by the scope of DI but commence DI with small steps. In other words, they might initiate it by differentiating presentation (not executed in this study), practice or production in the beginning. Apart from the steps of teaching, teachers might consider differentiating specific skills such as reading lessons, CLIL lessons in the first place so that they could see difficulties and possibilities, and thereby conveying it to teaching in general.

Fourthly, as DI requires plenty of time for preparation, it might be advisable to carry out DI with smaller groups for the sake of piloting, then generalizing it to more classes, and after that perhaps to the whole school.

The last recommendation for teachers is that it is imperative to invest in professional development in this field by reading about diverse DI strategies, observing colleagues, or watching videos reflecting DI. Otherwise, one might confuse DI with providing individual instruction, giving extra work to strong learners, or focusing attention on learners with learning difficulties.

Regarding recommendations for researchers, firstly, more research is needed in this field with a larger group of learners, which makes it more likely to generalize the results of the study. Secondly, similar research should be conducted in which teachers of the experimental group and control group are the same to increase reliability of the study. Thirdly, as this study was conducted with a four-week treatment period, further research could be conducted at a longer period, which will yield more sustainable and generalizable data. Lastly, to increase external validity of the study future research could apply DI with different levels and groups of learners such as upper intermediate young adults, advanced adults, or young learners.

\section{The Conflict of Interest Statement}

In line with the statement of Committee on Publication Ethics (COPE), I hereby declare that we had no conflicting interests regarding any parties of this study.

\section{References}

Affholder, L. P. (2003). Differentiated instruction in inclusive elementary classrooms (Unpublished doctoral dissertation). University of Kansas, Education Faculty, Kansas.

Alavinia, P., \& Farhady, S. (2012). Using differentiated instruction to teach vocabulary in mixed ability classes with a focus on multiple intelligences and learning styles. International Journal of Applied Science and Technology, 2(4), 27-82.

Aliakbari, M., \& Haghighi, J. K. (2014). On the effectiveness of differentiated instruction in the enhancement of Iranian learners reading comprehension in separate gender education. Social and Behavioral Sciences, 98, 182-189. https://doi.org/10.1016/j.sbspro.2014.03.405

Anderson, L.W. (1995). Individualized instruction. In L.W. Anderson (Ed.). Encyclopedia of teaching and teacher education, (pp. 155-161). Oxford: Pergamon.

Baumgartner, T., Lipowski, M., \& Rush, C. (2003). Increasing reading achievement of primary and middle school students through differentiated instruction. (Unpublished doctoral dissertation). Saint Xavier University, Education Faculty, Chicago. 
Beecher, M., \& Sweeny, S. M. (2008). Closing the achievement gap with curriculum enrichment and differentiation: One school's story. Journal of Advanced Academics, 19(3), 502-530. https://doi.org/10.4219/jaa-2008-815

Blaz, D. (2006). Differentiated instruction: A guide for foreign language teachers. Larchmont, NY: Eye on Education, Inc.

Boyatzis, R. E. (1998). Transforming qualitative information: Thematic analysis and code development. California: Sage.

Chien, C. W. (2012). Differentiated instruction in an elementary school EFL classroom. TESOL Journal, 3(2), 280-291.

Chung, S. F. (2005). Putting students' differences in perspectives: An introduction to the individual developing model. Asian EFL Journal, 7(2), 133-151.

Cohen, J. (1988). Statistical Power Analysis for the Behavioral Sciences (2nd Ed.). Hillsdale, NJ: Lawrence Erlbaum Associates, Publishers.

Creswell, J. W. (2012). Educational research: Planning, conducting and evaluating quantitative and qualitative research (4th Ed.). Boston: Pearson.

Danzi, J., Reul, K., \& Smith, R. (2008). Improving student motivation in mixed ability classrooms using differentiated instruction. Chicago, IL: Saint Xavier University and Pearson Achievement Solutions.

Dunn, R., \& Dunn, K. (1979). Learning styles/teaching styles: Should they...Can they... be matched? Educational Leadership, 36(4), 238-244.

Gardner, H. (1993). Frames of mind: The theory of multiple intelligences (2nd Ed.) London: Fontana Press.

Gardner, H. (2008). Multiple intelligences: New horizons. New York, NY: Basic Books.

Heacox, D. (2012). Differentiating instruction in the regular classroom: How to reach and teach all learners. Golden Valley, MN: Free Spirit Publishing.

Holland, J. L. (1997). Making vocational choices: A theory of vocational choices and work environments (3rd Ed.). Odessa, FL: Psychological Assessment Resources.

Karadağ, R., \& Yaşar, Ş. (2010). Effects of differentiated instruction on students' attitudes towards Turkish courses: An action research. Procedia Social and Behavioral Sciences, 9, 1394-1399. https://doi.org/10.1016/j.sbspro.2010.12.340

Kasteloot, B. A. (2011). Effects of differentiated mathematics instruction in a fourth grade classroom (Unpublished doctoral dissertation). Southwest Minnesota State University, Education Department, Minnesota.

Koeze, P. A. (2007). Differentiated instruction: The effect on student achievement in an elementary school (Unpublished doctoral dissertation). Eastern Michigan University, Department of Leadership and Counseling, Michigan.

Lewis, L. C., Rivera, A., \& Roby, D. (2012). Identifying and serving culturally and linguistically diverse gifted students. Waco, Texas: Prufrock Press Inc.

Liao, H. C. (2015). EFL learner perceptions of differentiated speaking assessment tasks. English Teaching and Learning, 39(1), 29-68.

Lunsford, K. (2017). Challenges to implementing differentiated instruction in middle school classrooms with mixed skill levels (Unpublished doctoral dissertation). Walden University, Education Faculty, Minnesota.

McCarthy, J. (2015). 3 ways to plan for diverse learners: What teachers do. Retrieved January 25, 2020 from: https://www.edutopia.org/blog/differentiated-instruction-ways-toplan-john-mccarthy

Miles, M. B., \& Huberman, A. M. (1994). Qualitative data analysis: An expanded sourcebook (2nd Ed.). California: Sage Publications. 
Njagi, M. W. (2014). Teachers' perspective towards differentiated instruction approach in teaching and learning mathematics in Kenya. International Journal of Humanities and Social Science, 4(13), 236-241.

Oliver, F. E. (2016). Teachers' perspective on differentiated instruction in the foreign language classroom (Unpublished master thesis). University of Iceland, Faculty of Teacher Education, Reykjavik.

Paone, N. A. (2017). Middle school teachers' perceptions of differentiated instruction: A case study (Unpublished doctoral dissertation). Northcentral University, Education Department, Arizona.

Paredes, J. P. (2017). The effect of differentiated instruction strategies in the learning of vocabulary, grammar and reading among EFL learners. Modern Journal of Language Teaching Methods, 7(3), 191-200.

Powers, E. A. (2008). The use of independent study as a viable differentiation technique for gifted learners in the regular classroom. Gifted Child Today, 31(3), 57-65. https://doi.org/10.4219/gct-2008-786

Ramos, L. A., \& Lasaten, R. C. S. (2018). Effect of differentiated instruction on students' level of engagement and performance in English. The Asian EFL Journal's International Conference on Research and Publication, Philippines, August 25, 2018.

Reid, J. M. (1984). Perceptual Learning Style Preference Questionnaire. Laramie: University of Wyoming, Department of English.

Reid, J. M. (1995). Learning styles in the ESL/EFL classroom. Boston: Heinle \& Heinle Publishers.

Robinson, L., Maldonado, N., \& Whaley, J. (2014). Perceptions about implementation of differentiated instruction. Annual Mid-south Educational Research Conference, Tennessee, November, 7, 2014.

Siam, K., \& Al-Natour, M. (2016). Teacher's differentiated instruction practices and implementation challenges for learning disabilities in Jordan. International Education Studies, 9(12), 167-181. https://doi.org/10.5539/ies.v9n12p167

Siddiqui, O., \& Alghamdi, F. (2017). Implementing differentiated instruction in EFL remedial classes. An action research. Education and Linguistics Research, 2(3), 89-100. https://doi.org/10.5296/elr.v3i2.11726

Stewart, O. S. (2016). Teachers' perceptions of differentiated instruction in elementary reading (Unpublished doctoral dissertation). Walden University, Education Faculty, Minnesota.

Suprayogi, M. N., \& Valcke, M. (2016). Differentiated instruction in primary schools: Implementation and challenges in Indonesia. PONTE, 72(6), $2-18$ http://dx.doi.org/10.21506/j.ponte.2016.6.1

Theisen, T. (2002). Differentiated instruction in the foreign language classroom: Meeting the diverse needs of all learners. Lote Ced The Communiqué, Retrieved January 16, 2020 from: https://www.sedl.org/loteced/communique/n06.pdf

Tomlinson, C. A. (1999). The differentiated classroom: Responding to the needs of all learners. Alexandria, VA: Association for Supervision and Curriculum Development.

Tomlinson, C. A. (2001). How to differentiate instruction in mixed-ability classrooms (2nd Ed.). Alexandria, VA: ASCD.

Tomlinson, C. A. (2005). Differentiating instruction; Why bother? Middle Ground, 9(1), 12-15.

Tomlinson, C. A. (2014). Differentiated classroom: Responding to the needs of all learners (2nd $E d$.). Alexandria, VA: Association for Supervision \& Curriculum Development (ASCD).

Tomlinson, C. A., Brighton, C., Hertberg, H., Callahan, C., Moon, T., Brimijoin, K., Conover, L., \& Reynolds, T. (2003). Differentiating instruction in response to student readiness, interest, and learning profile in academically diverse classrooms: A review of literature. 
Journal for the Education of the Gifted, 27(2/3), 119-145. https://doi.org/10.1177/016235320302700203

Tomlinson, C. A., \& Kalbfleisch, M. L. (1998). Teach me, teach my brain: A call for differentiated classrooms. Educational Leadership, 56(3), 52-55.

Tomlinson, C. A., \& McTighe, J. (2006). Integrating differentiated instruction \& understanding by design: Connecting content and kids. Alexandria, VA: ASCD.

Vygotsky, L. S. (1978). Mind in society: The development of higher mental processes. Cambridge, MA: Harvard University Press.

\section{Copyrights}

Copyright for this article is retained by the author(s), with first publication rights granted to the Journal.

This is an open-access article distributed under the terms and conditions of the Creative Commons Attribution license (CC BY-NC-ND) (http://creativecommons.org/licenses/by-nc-nd/4.0/). 